\title{
Pengelolaan Objek Wisata Desa Buluh Cina Untuk Meningkatkan Perekonomian Melalui Penambahan Sarana Dan Digital Marketing
}

\author{
M.Tazri ${ }^{1}$, Novia Rahmawati ${ }^{2}$, Muhammad Alief Rahman ${ }^{3}$ \\ ${ }^{1}$ Prodi Hubungan Masyarakat, Fakultas Ilmu Komunikasi \\ ${ }^{2}$ Prodi Akuntansi, Fakultas Ekonomi dan Bisnis \\ 3,Prodi Ilmu Komunikasi, Fakultas Ilmu Komunikasi \\ Universitas Muhammadiyah Riau \\ email: tazri@umri.ac.id
}

\begin{abstract}
Buluh Cina Village is a village that has the potential for natural and attractive natural attractions. The potentials that can be enjoyed include various unspoiled natural forests, there are also seven lakes, namely Lake Tanjung Putus, Lake Baru, Lake Pinang Luar, Lake Pinang Dalam, Lake Tuok Tonga, Lake Tanjung Balam, and Lake Rengas, there are also fishing objects , Tourist Boat Object, and Elephant Ride Object. However, these potentials are not managed optimally, because they are constrained by natural disasters and the lack of visitors visiting these attractions. Therefore, there have been initiatives to optimize the potential of BuluhChina village to become a tourism-rich village by promoting it through digital marketing. With this promotion, it is hoped that it can improve the community's economy through the empowerment of managed natural resources. This research uses research methods of socialization and mentoring techniques. From the results of this study, the increase in visitors after the renewal of tourist attractions and facilities experienced a significant increase from before the renewal.
\end{abstract}

Keywords: Tourism Objects, Digital Marketing, Economy

\begin{abstract}
Abstrak
Desa Buluh Cina merupakan desa yang memiliki potensi objek wisata alam yang masih alami dan menarik. Potensi yang dapat dinikmati diantaranya adalah berbagai hutan alam yang masih alami, terdapat juga tujuh danau, yaitu Danau Tanjung Putus, Danau Baru, Danau Pinang Luar, Danau Pinang Dalam, Danau Tuok Tonga, Danau Tanjung Balam, dan Danau Rengas, terdapat juga objek memancing, Objek Perahu Wisata, dan Objek Naik Gajah. Namun potensi-potensi tersebut tidak dikelola secara maksimal, dikarenakan terkendala oleh adanya bencana alam dan kurangnya pengunjung yang berkunjung ke objek wisata tersebut. Oleh karena itu muncul inisiatif-inisiatif untuk mengoptimalkan kembali potensi desa BuluhCina menjadi desa yang kaya akan wisata dengan melakukan promosi melalui digital marketing. Dengan adanya promosi tersebut diharapkan dapat meningkatkan perekonomian masyarkat melalui pemberdayaan sumber daya alam yang dikelola.Dalam penelitian ini digunakan metode penelitian teknik sosialisasi dan pendampingan. Dari hasil penelitian ini peningkatan pengunjung setelah ada nya pembaharuan objek wisata dan fasilitas mengalami peningkatan yang cukup signifikan dari sebelum adanya pembaharuan.
\end{abstract}

Kata Kunci: Objek Wisata, Digital Marketing, Perekonomian

\section{PENDAHULUAN}

Di Indonesia pariwisata memiliki berbagai ragam jenis, seperti wisata alam, sosial maupun wisata budaya, yang bertujuan dapat meningkatkan devisa Negara [1]. Salah satunya adalah wisata 
alam, Kegiatan wisata alam merupakan kegiatan rekreasi dan pariwisata pendidikan, penelitian, kebudayaan dan cinta alam yang dilakukan di dalam obyek wisata [2].

Desa BuluhCina merupakan salah satu desa yang berada di kecamatan Siak Hulu, kabupaten Kampar, Provinsi Riau . Desa Buluh Cina terkenal dengan sebutan sebagai "Desa Wisata", yang mana Desa Buluh Cina dikelilingi oleh beberapa danau dan hutan tropis yang sangat bagus. Adapaun untuk objek - objek wisatanya terdiri dari berupa wisata alam, yang mana di wisata alam ini terdapat berbagai hutan alam yang masih alami dan asri, dan diwisata alam ini juga terdapat berbagai Flora atau Fauna yang dapat dijadikan sebagai edukasi, terdapat juga 7 Danau, yaitu Danau Tanjung Putus, Danau Baru, Danau Pinang Luar, Danau Pinang Dalam, Danau Tuok Tonga, Danau Tanjung Balam, dan Danau Rengas, terdapat juga objek memancing. Objek Perahu Wisata, dan Objek Naik Gajah yang dikelola oleh pihak BUMdes

Secara umum mata pencaharian warga Desa Buluh Cina adalah nelayan, dan perkebunan, yang mana sebagian besar masyarakat memanfaatkan aliran sungai Kampar sebagai mata pencarian dengan melakukan pembudidayaan ikan dengan sistem keramba, ikan yang dihasilkan berupa ikan Patin, ikan Baung, ikan Tapah dan masyarakat juga memanfaatkan lahan yang luas sebagai perkebunan sawit.

Selain dua sektor mata pencaharian tersebut, desa BuluhCina memiliki potensi alam yang sangat bisa untuk dikembangkan menjadi objek wisata. Menurut Undang-Undang No. 10 tahun 2009,pasal 1 tentang kepariwisataan, yang dimaksud dengan pariwisata adalah berbagai macam kegiatan wisata dan didukung berbagai fasilitas serta layanan yang disediakan oleh masyarakat, pengusaha, pemerintah, dan pemerintah daerah.
Desa BuluhCina yang memiliki berbagai objek wisata yang masih alami, indah, dan keadaan alam yang masih menyejukkan, hal ini dapat terlihat melalui situs resmi website desa Buluh Cina yang menampilkan gambaran terkait objek wisata yang ada di desa Buluh Cina. Kesempatan seperti ini seharusnya tidak disia-siakan, dikarenakan sektor pariwisata sendiri merupakan sektor yang dapat mempengaruhi peningkatan ekonomi masyarakat sekitar. Sektor pariwisata juga merupakan sektor yang dapat menompang pertumbuhan perekonomian daerah jika di kelola dengan baik dan akan mengurangi ketergantungan daerah terhadap ekploitasi sumber daya alam di suatu daerah [3].

Seiring perkembangan zaman dan pesatnya perkembangan globalisasi saat ini sektor pariwisata dapat dengan mudah kita dapatkan informasinya melalui sarana digital marketing. Digital Marketing merupakan salah satu media pemasaran yang saat ini sedang banyak diminati oleh masyarakat untuk mendukung berbagai kegiatan yang dilakukan [4][5]

Dalam digital marketing kita dapat menyampaikan berbagai informasi memalui online, seperti melalui media social serta media massa online, dengan adanya media penyampaian informasi melalui digital ini sangat membantu untuk khususnya dalam sektor pariwisata, dikarenakan dapat dijadikan sebagai tempat promosi yang praktis, dan tidak memakai banyak biaya tetapi dapat berdampak sangat besar bagi peningkatan pengunjung.

Pada kegiatan kali ini kami tertarik untuk bekerja sama dengan pihak BUMDes Desa Buluh Cina untuk mengembangkan dan memperbaharui kembali objek wisata yang terdapat di Desa Buluh Cina ini menjadi bagus kembali. Untuk permasalahan yang didapati dari objek wisata Desa Buluh Cina ini, setelah melakukan wawancara dengan pihak BUMdes dan aparat desa 
lainnya, didapati bahwa desa Buluh Cina ini untuk objek wisatanya memiliki kendala dari jumlah pengunjung yang mengalami penurunan untuk berwisata, hal ini dikarenakan objek wisata nya masih kurang tertata rapi, kurangnya daya tarik yang didapat dari objek wisata tersebut, dan kurangnya informasi yang didapat oleh masyarakat luar untuk mengetahui adanya objek wisata tersebut.

Menurut pihak BUMDes, sebenarnya keberadaan berbagai objek wisata didesa Buluh Cina ini sendiri seharusnya dapat menjadi nilai perekonomian yang dapat dimanfaatkan oleh masyarakat sekitar untuk meningkatkan perekonomian dalam sektor internal desa, seperti masyarakat bisa memanfaatkan objek wisata tersebut untuk berjualan, menyewakan berbagai transportasi berupa penyewaaan sampan, rakit, dan lain sebagainya.

Oleh karena itu, pada kegiatan KKN kali ini, kami tertarik untuk memperbaiki kembali serta mengoptimalkan kembali objek wisata di Desa Buluh Cina dengan bekerja sama dengan pihak BUMdes untuk membuat objek wisatanya menjadi lebih menarik, dan diminati oleh banyak kalangan masyarakat. Dengan berbagai ide inovasi dan kreatifitas yang dikembangkan oleh tim kami diharapkan dapat menjadi motivasi bagi masyarakat sekitar untuk lebih peduli kembali terhadap objek wisata tersebut dan diharapkan dengan adanya pembaharuan kembali objek wisata tersebut dapat membantu perekonomian masyarakat.

Dengan melihat permasalahan yang telah dipaparkan tersebut, kami memberikan solusi yang dapat ditawarkan kepada pihak BUMDes dan masyarakat sekitar untuk mengatasi permasalahan objek wisata di Desa Buluh Cina ini adalah dengan memperbaharui kembali lokasi objek wisata tersebut, melakukan pembersihan lingkungan kembali, menambahkan berbagai spot-spot yang menarik seperti spot foto, spot tempat duduk santai, dan lain sebagainya dan mengekspos kembali objek wisata yang sudah diperbaharui tersebut melalui digital marketing dengan cara mempromosikan objek wisata di Desa Buluh Cina menggunakan berbagai social media, baik berupa Instagram, Facebook, Youtube, dan lain sebagainya, sehingga diharapkan dapat membantu perekonomian masyarakat.

\section{METODE PENGABDIAN}

Kegiatan pengabdian masyarakat melalui program Kuliah Kerja Nyata (KKN) tentang pengoptimalan kembali objek wisata guna penunjang perekonomian masyarakat melalui digital marketing didesa BuluhCina Kecamatan Siak Hulu Kabupaten Kampar. Waktu pelaksanaan kegiatan dari tanggal 30 Agustus sampai 30 September 2021. Yang menjadi objek sasaran dari kegiatan pengabdian ini adalah masyarakat desa BuluhCina.

Metode dalam pelaksanaan
kegiatan ini dilakukan dengan menggunakan beberapa teknik dan metode, yaitu Teknik Sosialisasi dan Pendampingan. Teknik Sosialisasi dan Pendampingan yang dimaksud adalah teknik yang digunakan untuk mengarahkan atau proses menuntun kegiatan dengan memberikan petunjuk atau pedoman untuk melaksanakan kegiatan. Dalam teknik pengarahan ini, tim KKN melakukan pengarahan terkait program kerja yang akan dilakukan di desa BuluhCina, pengarahan ini dilakukan dengan melalukan sosialisasi terkait program kerja yang akan dilaksanakan serta kegiatan-kegiatan lainnya yang akan dilaksanakan selama waktu KKN,dalam teknik pengarahan ini juga dilakukan bebarapa metode yang digunakan selama proses berlangsungnya proker KKN, yaitu dengan melakukan sosialisasi terkait program kerja serta bergotong royong untuk melakukan pembersihan objek wisata.

Teknik Pendampingan IPTEK. Agar pelaksanaan program dapat berjalan 
dengan baik, tentunya sangat diperlukan yang namanya pendampingan IPTEK, yang mana pendampingan ini akan membantu dalam penyampaian informasi maupun ilmu pengetahuan yang dapat digunakan oleh masyarakat desa BuluhCina, untuk pendampingan IPTEK sendiri kami membagi menjadi beberapa metode yang dapat digunakan, yaitu metode pembaharuan objek wisata dengan konsep Modern berbasis kearifan budaya lokal, Metode Pengenalan Objek wisata melalui situs Website dan Metode Promosi melalui digital marketing.

\section{HASIL DAN PEMBAHASAN}

Kegiatan Kuliah Kerja Nyata (KKN) ini diawali dengan melakukan persiapan pelaksanaan kegiatan, yaitu persiapan sosialisasi terkait program yang akan dijalankan, proses pembersihan danau, pendiskusian konsep yang akan digunakan, penentuan perlengkapan yang dibutuhkan, penambahan dekorasi dan renovasi fasilitas, finalisasi konsep, pembuatan website untuk promosi, dan melakukan promosi objek wisata.

Pada tahapan sosialisasi, tim melakukan persiapan sosialisasi kepada mitra, dalam hal ini mitra yang bekerja sama adalah BUMDes, dalam sosialisasi ini menjelaskan program kerja apa yang akan dilakukan serta proses apa yang akan digunakan untuk mempromosikan objek wisata di Desa BuluhCina.

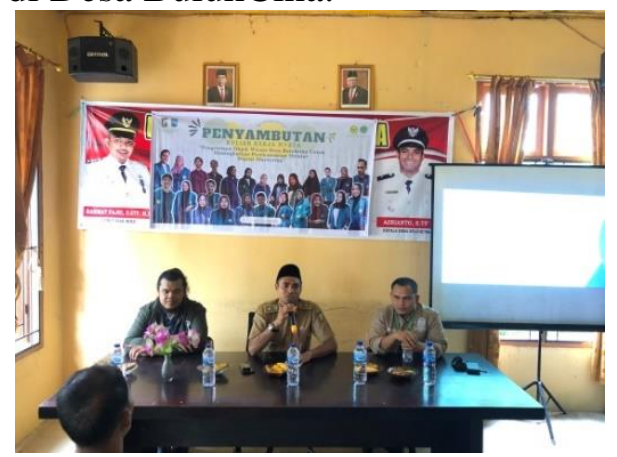

Gambar 1. Sosialisasi Program Kerja

Tahapan selanjutnya ialah proses pembersihan objek wisata, khususnya objek wisata Danau Rengas. Pada proses pembersihan ini, tim dibantu oleh pemuda sekitar untuk melaksanakan pembersihan lingkungan sekitar danau dengan cara bergotong royong, proses pembersihan yang dilakukan adalah membersihkan rumput, membakar sampah, menyapu dedaunan, memotong dahan-dahan yang menghalangi.

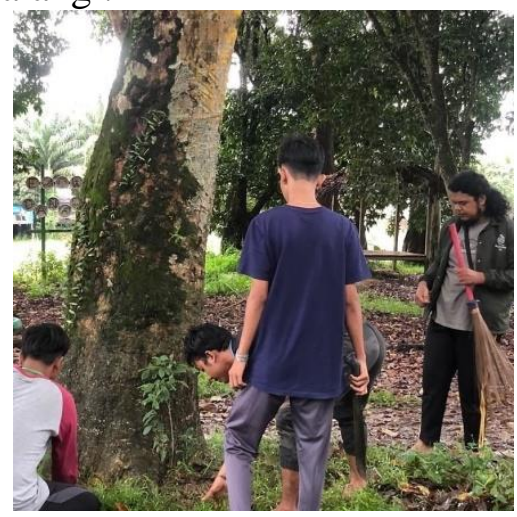

Gambar 2. Proses Pembersihan Danau Rengas

Proses selanjutnya ialah pendiskusian konsep yang akan digunakan, dalam proses diskusi ini tim memilih untuk melakukan konsep modern berbasis kearifan budaya lokal. Pada konsep ini tim ingin mengubah objek wisata menjadi lebih modern tetapi tetap memiliki ciri khas kearifan budaya lokal.

Proses selanjutnya adalah penentuan perlengkapan, dalam tahap ini tim mendiskusikan kembali terkait perlengkapan apa yang akan digunakan selama berlangsungnya kegiatan Kuliah Kerja Nyata (KKN) yang berkaitan dengan program kerja yang dikerjakan.

Tahapan selanjutnya ialah penambahan dekorasi dan renovasi fasilitas yang ada. Dalam tahapan ini tim melakukan renovasi terhadap fasilitas yang ada seperti perbaikan saung, serta gerbang pintu masuk objek wisata.

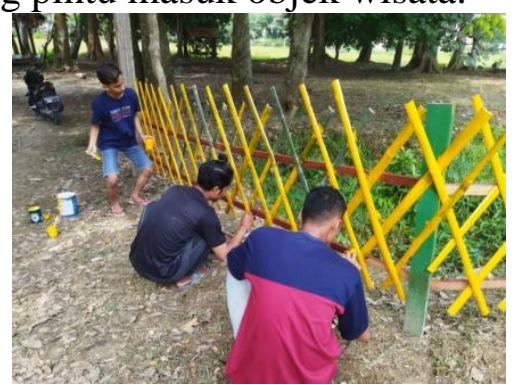

Gambar 3. Perbaikan Pintu Masuk 


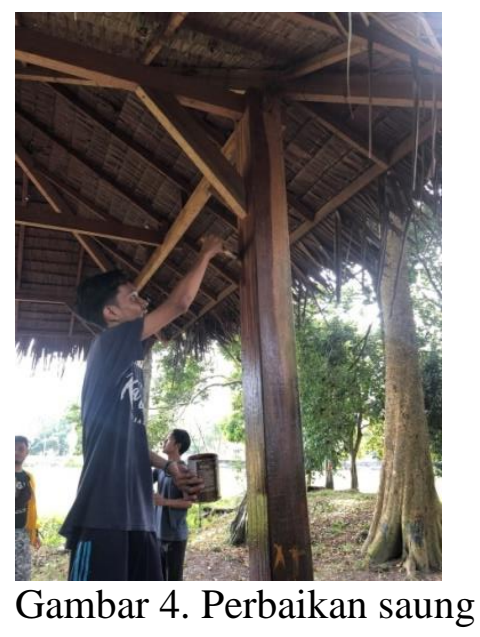

Tahapan selanjutnya adalah Penambahan dekorasi serta finalisasi konsep, dalam proses penambahan dekorasi tim melakukan penambahan spotspot foto yang dapat digunakan pengunjung untuk berfoto mengabadikan momen ketika mereka berwisata, penambahan spot foto ini, merupakan kiat yang digunakan untuk menarik perhatian pengunjung akan objek wisata tersebut.
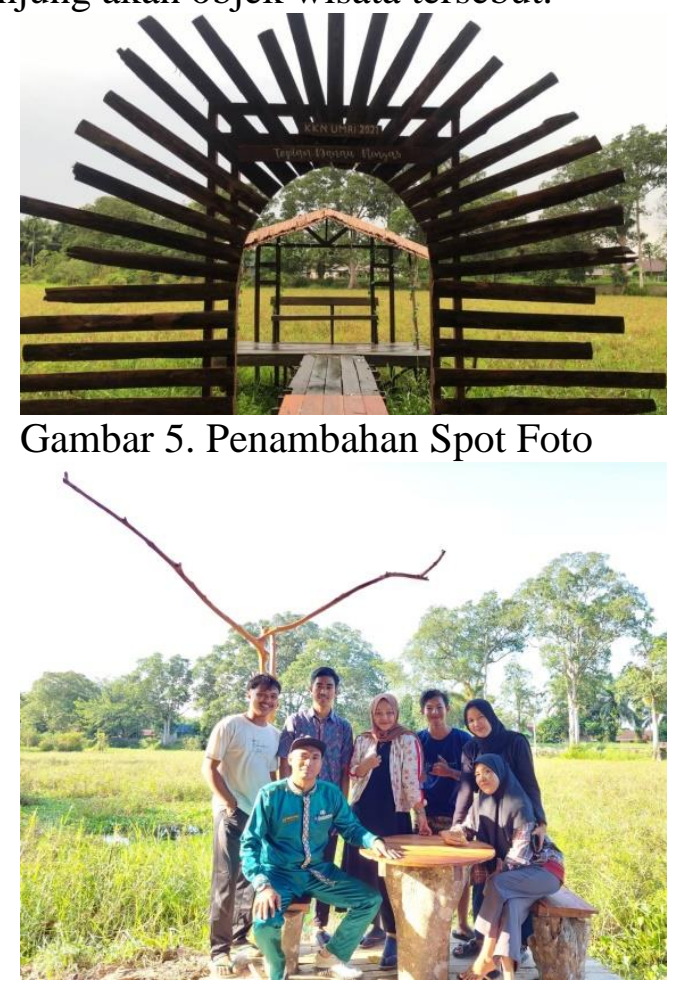

Gambar 6. Penambahan Spot Foto

Tahapan akhir yang dilakukan adalah pembuatan website serta mempromosikan objek wisata melalui sarana digital marketing, dalam tahapan ini tim membuat website berupa blog yang digunakan untuk media pengenalan dan informasi terkait objek wisata di Desa BuluhCina, dan tim juga melakukan promosi melalui digital marketing yaitu promosi melalui media social instagram, youtube, serta media massa online, dalam tahapan promosi ini diharapkan dapat membantu masyarakat untuk meningkatkan minat pengunjung untuk berkunjung ke objek wisata di Desa Buluhcina.

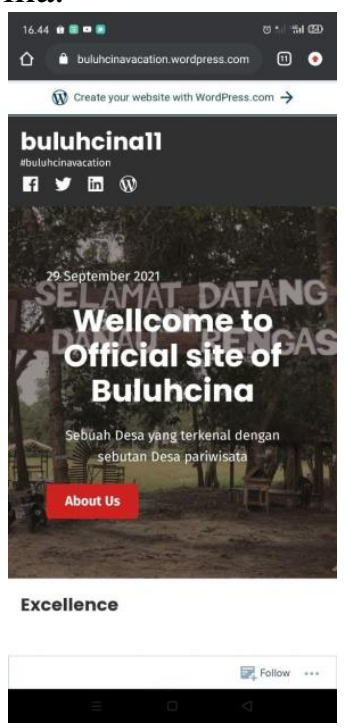

Gambar 7. Promosi melalui Blog

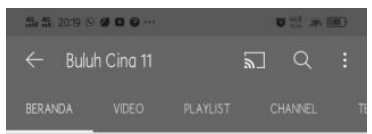

B Buluh Cina 11
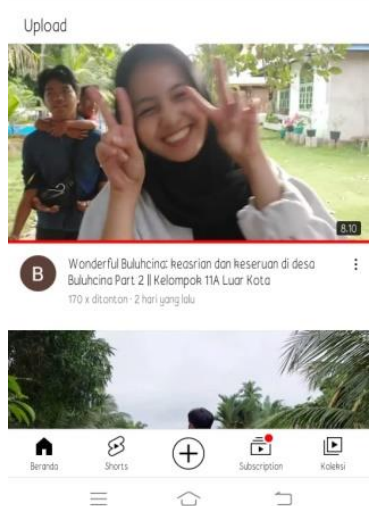

Gambar 8. Promosi melalui media social

\section{SIMPULAN}

Berdasarkan hasil dan pembahasan terkait program kerja Kuliah Kerja Nyata 
(KKN) dalam kegiatan pengoptimalan kembali objek wisata di Desa BuluhCina yang dilakukan oleh mahasiswa Universitas Muhammadiyah Riau, simpulan yang dapat diambil dari kegiatan ini adalah sebagai berikut:

1. Setelah dilakukan kegiatan pengabdian ini, maka sarana/fasilitas penunjang yang ada dilokasi wisata menjadi lebih menarik dan bertambah, sehingga dapat menarik minat pengunjung.

2. Dengan adanya pembuatan website dan pemanfaatan media sosial diharapkan dapat meningkatkan promosi di Desa Buluh Cina.

Setelah dilakukannya pembaharuan terhadap objek wisata dan penambahan fasilitas, peningkatan pengunjung mulai mengalami peningkatan dibandingkan dengan sebelumnya.

\section{UCAPAN TERIMAKASIH}

Kami mengucapkan terima kasih kepada:

1. Lembaga Penelitian dan Pengabdian Kepada Masyarakat (LPPM) Universitas Muhammadiyah Riau sebagai lembaga yang memberikan pengarahan terkait program Kuliah Kerja Nyata (KKN).

2. Pihak BUMDes Desa BuluhCina sebagai mitra yang bekerja sama untuk mensukseskan program kerja yang dilaksanakan.

3. Perangkat desa BuluhCina kecamatan Siak Hulu, Kabupaten Kampar yang telah memberikan izin dan dukungan selama pelaksanaan program pengabdian Kuliah Kerja Nyata $(\mathrm{KKN})$

Serta masyarakat desa BuluhCina yang telah berpartisipasi untuk mensukseskan pelaksanaan program Kuliah Kerja Nyata( $\mathrm{KKN}$ ) yang sudah direncanakan.

\section{DAFTAR PUSTAKA}

[1] Devy \& Soemanto, "Pengembangan Obyek Dan Daya Tarik Wisata
Alam Sebagai Daerah Tujuan Wisata Di Kabupaten Karanganyar," J. Sosiol. DILEMA, vol. 32, no. 1, pp. 34-44, 2017.

[2] S. Romani, "11 . Penilaian potensi obyek $n$ daya tarik WA serta alternatif perencanaanya di $\mathrm{TN}$ BDuabelas Jambi,” 2006.

[3] I. P. Dinata and M. Mussadun, "Pengaruh Pengembangan Kawasan Wisata Geopark Merangin Terhadap Kesejahteraan Masyarakat Desa Air Batu," $J$. Pembang. Wil. Kota, vol. 11, no. 3, p. 328, 2015, doi: 10.14710/pwk.v11i3.17585.

[4] Achmad Room Fitrianto, Oslam Ahmadia, Siti Hasna Madinah, Churin Iin, Muhammad Fauzin Nur, and Zahrotun Nadhifa, "Optimalisasi Potensi Desa Wisata Edukasi di Ledug Prigen," $J$. Pengabdi. UntukMu NegeRI, vol. 4, no. 2, pp. 276-284, 2020, doi: 10.37859/jpumri.v4i2.2152.

[5] T. Pradiani, "Pengaruh Sistem Pemasaran Digital Marketing Terhadap Peningkatan Volume Penjualan Hasil Industri Rumahan," J. Ilm. Bisnis dan Ekon. Asia, vol. 11, no. 2, pp. 46-53, 2018, doi: 10.32812/jibeka.v11i2.45. 